\title{
Lost Revenue Due to Trade Liberalization: Can Nigeria recover her own?
}

\author{
Nathaniel E. Urama ${ }^{1}$, Emmanuel O. Nwosu ${ }^{2}$ and Gladys C. Aneke ${ }^{3}$ \\ 1, 2: Department of Economics, University of Nigeria Nsukka, Enugu state, Nigeria, and \\ African Institute for Applied Economics, 54 Nza Street, GRA, Enugu state, Nigeria. \\ 3: Economics Department, University of Nigeria Nsukka, Nigeria \\ *E-mail of corresponding author: unathaniel@ymail.com
}

\begin{abstract}
The aim of the study is to find out the possibility of recovering the tariff revenue that will be lost in the process of liberalization through restructuring of the domestic tax system in Nigeria by examining the buoyancy and elasticity of the tax system. Using the dummy method, commonly known as the Singer approach, the Nigerian tax system as a whole was found to be relatively buoyant but not elastic. The buoyancy however showed a decline close to $16 \%$ after the 1991 trade reform. Import duty despite the decline in its share in total tax from $47.3 \%$ before the reform to $28 \%$ over the reform period showed a positive increase in buoyancy. CIT collection measured by tax-to-base elasticity declined by $46 \%$ over the reform period, suggesting that there is an urgent need to improve on tax administration. Also, the result confirm the ineffectiveness of the various reforms and (DTMs) in enhancing the productivity of the tax system, showing that much need to be done in our domestic tax system, both in structure and administration before thinking of engaging in any bi- or multilateral trade agreement.
\end{abstract}

Key words: Nigeria, Trade liberalisation, Lost revenue and Domestic tax system

\subsection{Introduction}

Nigeria government in 2003 adopted a new trade policy in line with an overall economic development package called the National Economic Empowerment and Development Strategy (NEEDS). NEEDS was described as Nigeria's plan for prosperity and the vision for a greater tomorrow. With the aim to achieve its objectives, NEEDS focused on four key strategies: reorienting values, reducing poverty, creating wealth and generating employment. These key visionary goals were again built into three major macroeconomic frameworks, namely: empowering people, promoting private enterprise and changing the way government does its work (NEEDS 2005).

In the Trade Policy area, NEEDS seeks to deepen Nigeria's integration with the rest of the world and to maximise the benefits of strategic integration (NEEDS 2005). Thus Regional Integration and trade are the two instruments identified by NEEDS for maximising the benefits of globalisation. The trade policy objective under NEEDS is to gradually liberalise trade and lay a solid foundation for full exploitation of Nigeria's potentials in international trade and helping her to become the gateway to West and Central Africa.

Against the above background, under NEEDS, the trade policy thrust is to drastically reduce the uncertainty and unpredictability of the trade policy regime, harmonise trade practices with those of other ECOWAS countries and hence facilitate full integration, respect obligations under multilateral and regional trading systems and create a conducive and competitive environment in which Nigerian enterprises can thrive and effectively compete in the global and regional economy.

\subsection{Problem Statement}

The above NEEDS trade policies are those of trade liberalization which has been a major concern of industrialized countries for years now. They have much emphasized the gains from trade liberalization for both the developed and the developing countries (Sachs and Warner, 1995; Edwards, 1998; Bhasin, 2006; World Bank, 2002; Winters et al., 2004). These were supported by the positive impact of trade liberalisation on Government revenue found by Inye, (2005), Baunsgaard and Keen, (2004) and, Wacziarg and Welch (2003). The World trade Organization estimates that the elimination of tariff would result in developing countries' income gain of $\$ 500$ billion and would lift more than 200 million people out of poverty by 2015 (WTO Addendum, April 2003). These tends to lure developing countries into trade agreements with each other and with 
the developed countries as exemplified by ECOWAS Common External Tariff (CET), which targets establishment of common external tariff of 5\%,10\% and $20 \%$ among the ECOWAS countries, Union Economique et monetaire Quest Africaine (UEOMAO), Which targets a tariff rate that is 35\% less than the Nigerian average tariff rate, EU- ACP countries partnership agreement, which aims at preferential trade policy and establishment of the same tariff rate among EU and ACP countries (Kuji, 2002).

Despite all the emphasized gains from trade liberalization, Stevens and Kennan (2005a and b), Stephen (2005c) and Rodriguez, et al. (2001), are of the opinion that if African, Caribbean, and Pacific (ACP) countries should reduce their tariff on import from EU, it will have potential 'revenue' and 'competition' effect. This according to them may not be in favour of the developing countries. In Nigeria, it has been found that trade liberalization has been negatively correlated with growth of the GDP (Nwafor, 2004). Kola-Ige, (2006) shows that a policy of harmonizing tariffs to the common external tariff of the European community has virtually no effect on welfare. Nwafor, Ogujiuba and Adenikinju (2005) found that despite oil revenue, adopting CET tariff band will reduce poverty in the urban area in the short and the long run, but will increase poverty in the rural areas in both the short and long run, thereby increasing income inequality in Nigeria. In support of this, Banerjee and Newman found that even if global economic integration induces faster economic growth in the long run and substantial reductions in poverty, the adjustment might be costly, with the burden falling disproportionately on the poor (Banerjee and Newman, 2004). These therefore, signify that Nigeria and most of the developing countries may not be reaping the benefit of trade liberalization as the developed countries and the WTO emphasized.

The possible cause of this negative relationship between trade liberalization and Economic growth may be the fact that trade liberalization results in decreased fiscal revenue of the government which reduces public savings (Bhasin 2006). The work of African trade Policy Centre (ATPC) shows that negative fiscal impacts emerge at later stages of liberalization. The boost of revenues from higher trade volumes as a result of tariff cuts is insufficient to outweigh the revenue-damping effect of the tax reductions (ATPC, 2004). Bhasin also noted that developing countries may not choose to liberalize their trade despite the potential gains because of two important considerations; the loss in revenue due to tariff reduction and the potential economic and social disruption caused by rapid displacement of workers from agriculture. The World Trade Organization in its 11 April 2003 Addendum stated that for many developing countries, tariffs have been an important source of government revenue and the elimination of tariffs could have serious consequences for their fiscal stability. It was further stressed there that, genuine trade liberalization must nevertheless, eventually result in reduced tax revenue and hence, will raise difficult fiscal issues if appropriate steps are not taken to strengthen the domestic tax system (WTO Addendum, April 2003). Nigerians should be more concerned to this issue. Our tariff is among the highest world wide, ranging from $2.5-150 \%$ as at 2004 and reducing it to $0-20 \%$ as demanded by the ECOWAS, for example, will mean a heavy loss in revenue. These coupled with the fact that Nigerians is a mono product economy and has preference for imported products makes the question of whether Nigerian government actually recovers revenue lost from tariff reduction a very important one.

Earlier research works revealed that the lost revenue from trade liberalization could be compensated for if appropriate fiscal reforms are taken in the concerned economy. From the findings of WTO and Liam et al., (1999), the revenue effect of trade liberalization can be mitigated by building on the domestic tax reforms. The decreased public savings could also be compensated for by an increase in foreign savings (Bhasin 2004), and by expanding the volume of import and export (Baunsgaard and Keen, 2004).

Among all these means of compensating for the loss in revenue as a result of trade liberalization, the most likely one for Nigeria as a mono product economy is that of reforming the domestic tax system. However, it was noted that the ability of the tax system to mobilize sufficient revenue depends on its buoyancy and elasticity (Ademola, 1997; Asher, 1989; Kabbashi, 2005; and Daniel et al., 2010). Therefore, the question of how buoyant and elastic the domestic tax system is becomes necessary in determining to what extent the Nigerian government recovers her lost tax revenue from trade liberalisation.

The aim of the study is therefore is to determine the buoyancy and elastic the domestic tax system as a way of predicting the revenue implication of trade liberalization in Nigeria 


\subsection{MODEL SPECIFICATION}

Tax Buoyancy and elasticity measures increases in tax revenue due to increase in income (Osoro, 1993); Ademola, 1997; BILQUEES 2004; Kabbashi, 2005; and Daniel et al., 2010). When no attempt is made to control for discretionary measures that alter the tax rate and/or base, then the responsiveness of tax revenue to change in income is the tax buoyancy. Controlling for such measures yields estimates of tax elasticity. Buoyancy greater than elasticity suggests that discretionary tax measures (DTMs) improve revenue mobilization of the tax, while buoyancy less than elasticity implies that revenue mobilization worsen as a result of the introduction of the DTMs.

The discretionary tax measures (DTMs) are under the control of the policy makers, generally these are due to changes in tax rate, base definition as well as changes in collection and enforcements of tax law. While non-discretionary changes are due to the natural growth of the economy. The global buoyancy of a tax system is usually measured by the proportional change in total tax revenue with respect to the proportional change in national income.

According to Gujarati (2006), Kabbashi (2005), Osoro (1995) and Ademola (1997), a good way of estimating the buoyancy and elasticity is by the use of exponential model of the form:

$$
T=\alpha Y^{\beta} \varepsilon_{t}
$$

Where $\mathrm{T}$ is the tax revenue and $\mathrm{Y}$ is the national Income. Equation (1) can be transformed into double log form following fixed-effect model:

$$
\log \hat{T}_{t}=\log \hat{\alpha}+\hat{\beta} \log Y_{t}+\varepsilon_{t}
$$

Here, $\hat{\beta}$ is the OLS estimate of buoyancy (or elasticity), $\hat{\alpha}$ is a constant term indicating tax yield when the base is set to zero (Osoro 1993; Ariyo 1997; Teera 2002; Tanzi, 2003; and Jha 2004).

Two techniques are in use for cleansing data in order to control for the impact of the discretionary tax measures DTMs and hence obtains estimates of tax elasticity. These are the historical time series tax data (HTSTD) adjusted for DTMs (Mansfield, 1972; Sury, 1985 and Osoro, 1993) and the unadjusted HTSTD with time trends or dummy variables introduced as proxies for DTMs (Andersen, 1973; Choudhry, 1975; Singer, 1968; and Artus, 1974). In this study, the dummy method, commonly known as the Singer approach was used, thereby changing equation (2) to:

$$
\log T_{t}=\log \hat{\alpha}+\text { 瓷 } \log Y_{t}+\beta_{2} \log Y_{t-1}+\sum_{i=1}^{3} \beta_{3 i} D_{i}+\beta_{4} \text { trend }+\varepsilon_{t}
$$

where $D_{i}$ stands for three dummies, $Y_{t-1}$ stands for one period lag of GDP.

The two-step dummies are introduced to account for the tax reforms in Nigeria within the period of analysis. The first reform took palace in 1991 and the second reform in 2002 (Ayodele, 2006). One slope dummy was introduced to allow for change in the slope of the tax revenue function over the trade liberalization period. The expectation is that over this period not only the intercept but also the slope of the function may change. The trend term is included to account for innovation in the Nigerian tax system as a result of the numerous changes in tax measures introduced over the sample period. Finally the lagged base is introduced to account for the administrative efficiency, or otherwise, in tax collection.

Models (2) and (3) will be applied to the total tax revenue (TTR) and its disaggregated sources (Personal Income Tax (PIT), Corporate Income tax (CIT), Import Duties(IM.D), Excise Duties(ED ), Indirect Tax(IND.T), and Direct Tax(Dir. T)) in order to get estimates, respectively of tax buoyancies and elasticities. 


\subsection{Empirical Results}

\subsection{Buoyancy}

Table 1 contains the estimated results for the buoyancy of the taxes in Nigeria. The buoyancy coefficients for total tax revenue (TTR) and Personal income tax (PIT) are1.1 and 1.2 respectively, which show that they are generally buoyant. These results are comparable with those obtained from other similar country studies (see e. g. Osoro, 1993; and Muriiti, 2003;).Those of Import duty, Excise duty, and CIT are all less than one, showing that these taxes are not buoyant. The low buoyancy on international trade might be due to tax evasion, tax exemptions, corruption in tax administration, and the presence of the underground economy.

In order to compare the performance of the tax system before and after liberalization, nominal estimates of the intercept and the coefficients for different taxes over 1970-91 and 1992-2010 were reported in tables (2). As seen, the buoyancy of the TTR showed a decline close to $16 \%$ after the reform where as Import duty despite the decline in its share in total tax from $47.3 \%$ before the reform to $28 \%$ over the reform period showed a positive increase in buoyancy.

The decomposed buoyancies can be used to investigate the sources of loopholes in revenue leakages. Table (3) presents a summary of decomposed nominal measures of buoyancies of the major tax sources. The highest growth of base-to income occurs in the case of Corporate Income Tax indicating a high growth of taxable business profit. However, Corporate Income Tax collections, measured by tax-to-base elasticity, declined by $46 \%$ over the reform period suggesting that there is an urgent need to improve the administration of collection of this tax.

\subsection{Elasticity}

Nominal estimates of the elasticities of the major taxes and of total tax revenue using Singer's approach are shown in table (4). As seen in the table the overall elasticity is 0.82 , while the elasticities of individual taxes were divergent. The elasticity of import duties, the main non oil tax in the country, was 0.83 . Excise tax has an elasticity of 0.82 , while both income and profit tax had respectively elasticities of 1.26 and 1.57 .

The overall tax elasticity of 0.82 implies that the growth of tax yield in proportion to the nominal growth of the economy is low. The elasticities of the income and profit taxes were greater than unity. However, the lagged base is negative implying that there were substantial administrative inefficiencies in the collection of these taxes.

The liberalization dummy was significant only for Income Tax. However the slope shift dummy was significantly positive making it difficult to assess the impact of liberalization on tax yield from this source. These two coefficients were not significant for the other tax handles indicating that liberalization don't have much effect on these revenue sources. The dummy for tax reform over 1991/92 was significantly negative for income and profit taxes. The negative sign on this variable for these and other taxes reflects the effects of the confusion created in the tax system resulting from the replacement of the conventional tax handles with new ones.

The trend coefficient was significantly negative for excise tax implying that the various reforms and innovations in the tax system failed to raise revenue from this tax source. This coefficient picked up the declining trend of the excise tax resulting from weak administration and the various tax exemptions schemes introduced to encourage local production and import-substituting industrialization.

Table (5) provides a summary of estimated values of the constants and coefficients for buoyancy and elasticity using nominal variables over the sample. As seen in the table, the difference between the estimated coefficients of the overall buoyancy and elasticity is positive and relatively large. However, the values of estimated constants move in different directions over the sample making it difficult to confirm that the various discretionary tax changes improve tax yield. The same observation applies to the excise duties. In contrast, for the personal income and business taxes the difference between buoyancy and elasticity were large and significant, and since the values of estimated constants move in the same direction it can be concluded that the various (DTMs) appear not to improve tax yields from these sources. In the case of import duties the values of estimated constants and coefficients move in the same direction implying that for any one percent increase in GDP the discretionary tax changes mobilize an additional 0.04 percent of revenues from import duties. 
Table (6) shows a summary of the estimates of real measures of buoyancy and elasticity. Despite the statistical insignificance of many estimated coefficients, the reported results parallel the earlier ones and confirm the ineffectiveness of the various reforms and (DTMs) in enhancing the productivity of the tax system. The significant and relatively high estimates of real measure of the excise duties indicate that the composition of total tax is skewed away from trade and income taxes towards domestic indirect tax.

The less buoyant and inelastic tax system, provide an explanation for the low tax efforts, which in turn implies negligence of the productive sectors of the economy. There is a considerable danger that, the rise in windfalls associated with the boom in oil sector, may provide lack of incentive to develop alternative tax bases and/or improve the existing ones, with the obvious result of reducing public accountability, inducing destructive rent seeking activities and an efficient allocation of the resources in the economy.

\section{Conclusion and Recommendation}

There has been and increasing pressure from the developed world for the developing nations to liberalize their trade with highlights of the gain from trade liberalization. These lead to series of research to find out, if actually the developing countries will benefit both in the short and long run from the action. Most of the results indicated that the ability of the developing countries to benefit from trade liberalization depends on whether it can recover the tariff revenues it will loss from liberalization. Among the identified means of doing this, that of restructuring the domestic tax system was found more applicable to Nigeria.

This work therefore seek to find out the possibility of restructuring the domestic tax system in Nigeria by examining the buoyancy and elasticity of the tax system using the dummy method, commonly known as the Singer approach.

The Nigerian tax system as a whole was found to be relatively buoyant but not elastic. The buoyancy of the TTR showed a decline close to $16 \%$ after the reform where as Import duty despite the decline in its share in total tax from $47.3 \%$ before the reform to $28 \%$ over the reform period showed a positive increase in buoyancy. CIT collection measured by tax-to-base elasticity declined by $46 \%$ over the reform period, suggesting that there is an urgent need to improve on the tax administration. Also, the result confirm the ineffectiveness of the various reforms and (DTMs) in enhancing the productivity of the tax system.

From the findings of this work, it is clear that much need to be done in our domestic tax system, both in structure and administration for according to Osoro, (1995), reforms in tax structure that is not accompanied by administrative reforms is bound to be useless. It is therefore recommended that the immediate policy objectives of the Nigerian government before thinking of engaging in any bi- or multilateral trade agreement should be on restructuring the domestic tax system by diversifying the tax base and improving the tax administration system.

\section{References}

Ademola, Ariyo. (1997). Productivity of the Nigerian Tax System: 1970-1990. African Economic Research Consortium, Nairobi, Research Paper 67.

Andersen, S. P. (1973). Built-in Flexibility of Sensitivity of the Personal Income Tax in Denmark. Swedish Journal of Economics vol. 75.

Ariyo, A. (1997). Productivity of the Nigerian Tax System: 1970-1990. AERC Research Paper No. 67.

Artus, K. K. (1974). Tax Revenue Forecasting: A Methodological Study with Application to Turkey. Studies in Domestic Finance no. 5.

Asher, M. G. (1989). Fiscal System and Practice in ASEAN: Trends, Impact and Evaluation. Singapore Institute of South East Asian Countries

ATPC, (2004). Fiscal Implications of Trade Liberalization on African Countries. ATPC Work in Progress, No. 5 Ayodele Odusola(2006), Tax Policy Reforms in Nigeria. UNU-WIDER, Research Paper No. 2006/03.

Banerjee, Abhijit and Andrew Newman, (2004). Inequality, Growth and Trade Policy. mimeo, MIT, Baunsgaard,T and Keen, M. (2004). Tax Revenue and (or?) Trade Liberalization. Fiscal Affairs Department, International Monetary Fund, Washington D.C., 20431 
Bhasin V. K. (2006). Trade Liberalization, Foreign capital inflows, Poverty and Income Distributions of Households in Ghana. Proposal to African Economic Research Consortium

Choudhry, N. N. (1975). Measuring the Elasticity of Tax Revenue: A Divisia Index Approach. IMF Staff Paper, vol. 36 pp 87-122.

Christopher S. (2005). Economic Partnership Agreements and African integration: a help or a hindrance?

Daniel K. T., Abel F., Eric O. A. And Emmanuel E. A. (2010). Buoyancy And Elasticity of Tax: Evidence from Ghana. Journal of monetary and Economic integration, vol. 10, No. 2

Edwards, Sebastian (1998). Openness productivity and growth: what Do We Really Know?. Economic Journal 108: 383-398.

Bilquees F. (2004). Elasticity and Buoyancy of the Tax System in Pakistan. The Pakistan Development Review $43: 1$ pp. $73-93$

Gujarati D. N (2006). Basic Econometrics. (5 $5^{\text {th }}$ ed.). USA: Tata McGraw-Hill Publishing Company limited, (Chapter 6).

Inye N. B. (2005). Nigeria: Protecting Domestic Productions in Times of Liberalisation and the Short, Medium and Long Term Implications for Regional Integration. Presented at the ECOWAS Regional Workshop on Multilateral Trade Agreements, $I M F$

Jha, R. (2004). Macroeconomic Stabilization and Pro-Poor Budgetary Policy in the Globalize Economy. CAMA Working Paper 8/2004.

Kabbashi M. S. (2005). The Impact of Trade Liberalisation on Revenue Mobilization and Stability in Nigeria. A revised report submitted to the: International Research Project on Macroeconomic Policy Challenges of Low Income Countries 2005 organized by the GDN.

Kola Ige F.C.E. Economic Benefits of Trade Liberalization: The Case of Nigeria in the New Millennium. A paper presented at the National conference of the Institute of certified Economist of Nigeria held in Lagos November, 2006.

Kuji LTD. (2002). Comprehensive Review of the Nigerian Customs and Excise Tariff 1995 - 2001: Implications for Nigeria of The ECOWAS Common External Tariff and Nigeria's Obligations/commitments under WTO, ECOWAS, AGOA AND ACP-EU.

Liam E., Janet . and Reint G. (1999). Revenue Implications of Trade Liberalization, IMF Occasional Paper No.180. Washington:

Mansfield, C. Y. (1972). Elasticity and Buoyancy of a Tax System: A method applied to Paraguay", IMF Staff Papers Vol. 19.

Muriiti M.K (2003). Tax Reforms and Revenue Mobilization in Kenya. AERC Research Paper no. 131.

Nwafor, M. Ogujiuba K. and Adenikinju A (2005). The Impact of Trade Liberalization on Poverty in Nigeria: Micro simulation in A CGE Model. Interim report to the PEP Research Network.

Nwafor, M. (2004). Trade Liberalization and Poverty in Nigeria: Lessons from the Past": African Institute for Applied Economics, Nigeria.

Osoro. N. E. (1993). Revenue Productivity Implications of Tax Reform in Tanzania”, AERC Research Paper no. 20

Osoro. N. E. (1995). Tax Reforms in Tanzania: Motivations, Directions and implications AERC Research Paper no. 38.

Rodriguez, F. and Dani R. (2001). Trade Policy and Economic Growth: A Sceptics Guide to the Cross- National Evidence, in Ben B. and Kenneth S. Rogoff, eds. NBER Macroeconomic Annual 2002, MIT Press for NBER.

Sachs J. and Andrew W. (1995). Economic Reform and the Process of Global Integration. Brookings paper on Economic activity, 1-118.

Singer, N. M. (1968). The Use of Dummy Variables in Establishing the Income Elasticity of State Income Tax Revenue. National Tax Journal vol. 61 pp 83-90.

Stevens, C. and J. Kennan. (2005a). Assessment of the Proposed Reform of the Generalized System of Preferences. Institute of Development Studies.

Stevens, C. and J. Kennan. (2005b). EU-ACP Economic Partnership Agreements: The Effects of Reciprocity. Institute of Development Studies. 
Sury, N. M. (1985). Buoyancy and Elasticity of Union Excise Tax Revenues in India: 1950-51 to $1980-81$. National Council of Applied Research vol. 18, 41-56

Tanzi, V. (2003). Trade Liberalization and Trade Tax. Trade and Integration Network.

Teera, J. (2002). Tax Performance: A Comparative Study. Department of Economics, University of Bath Working Paper. No. 01.

Wacziarg, R. and Welch, K. H. (2003). Trade liberalization and growth: New evidence. NBER Working Paper 1015

Winters, A. Neil M. and Andrew M..(2004). Trade Liberalization and Poverty: the Evidence so far", Journal of economic literature 62: 72-115.

World Bank. (2002). Global Economic Prospects.

WTO. (2003). Revenue Implications of Trade Liberalization": Market Access for Non-Agricultural Products TN/MA/W/18/Add.2. Communication from the United States Addendum

Table (1):

\section{Appendix A}

\begin{tabular}{llllllll}
\hline & Constant & Coefficient & S.E. & t-value & $\mathbf{R}^{\mathbf{2}}$ & D.W & P-value \\
\hline Total tax revenue & -3.9378 & 1.1028 & 0.0482 & 22.858 & 0.9389 & 2.18 & 0.0000 \\
\hline Personal Income Tax & -4.0316 & 1.2123 & 0.7935 & 1.528 & 0.9040 & 1.68 & 0.1367 \\
\hline CIT & -7.1112 & 0.7714 & 0.6025 & 1.280 & 0.9505 & 1.93 & 0.2099 \\
\hline Import duties & -3.9327 & 0.5446 & 0.2205 & 2.469 & 0.9907 & 1.43 & 0.0190 \\
\hline Excise tax & -3.0572 & 0.9578 & 0.2339 & 4.0949 & 0.9994 & 2.01 & 0.0000 \\
\hline
\end{tabular}

Estimates of tax buoyancy in Nigeria 1970-2010

Table (2):

\begin{tabular}{|c|c|c|c|c|c|}
\hline \multirow[t]{2}{*}{ Equation } & \multicolumn{2}{|c|}{ 1970-1991 } & \multicolumn{2}{|c|}{ 1992-2010 } & \multirow{2}{*}{$\begin{array}{l}\text { Difference in } \\
\text { coefficient }\end{array}$} \\
\hline & Constant & Coefficient & Constant & Coefficient & \\
\hline $\begin{array}{l}\text { Total } \\
\text { Revenue }\end{array}$ & -1.1825 & 0.8814 & 1.5425 & 0.7418 & -0.1396 \\
\hline $\begin{array}{l}\text { Personal Income } \\
\text { Tax }\end{array}$ & -3.3506 & 1.002 & -0.3766 & 0.6742 & -0.3278 \\
\hline CIT & -4.1117 & 0.9670 & -3.1000 & 0.7320 & -0.235 \\
\hline Import Duties & -1.9753 & 0.9474 & -3.224 & 1.0023 & 0.0549 \\
\hline Excise Tax & -3.5590 & 0.8690 & -1.5144 & 0.6893 & -0.1797 \\
\hline
\end{tabular}

Comparison of Tax buoyancies over 1970-91 and 1992-2010 
Table (3):

\begin{tabular}{llll}
\hline Period & $\mathbf{1 9 7 0 - 1 9 9 1}$ & $\mathbf{1 9 9 2 - 2 0 1 0}$ & Difference \\
\hline & (A) Base-to-Income Elasticity & & \\
\hline Personal Income Tax & 0.8220 & 0.8778 & 0.0518 \\
\hline CIT & 0.8997 & 1.3890 & 0.04893 \\
\hline Import Duties & 1.0020 & 0.8660 & -0.136 \\
\hline Excise Tax & 0.9801 & 0.7721 & -0.2081 \\
\hline
\end{tabular}

\section{(B) Tax-to-Base Elasticity}

\begin{tabular}{llll} 
Personal Income Tax & 0.6357 & 0.4442 & -0.1915 \\
\hline CIT & 1.0377 & 0.6003 & -0.4374 \\
\hline Import Duties & 0.3205 & 1.0281 & 0.7076 \\
\hline Excise Tax & 0.8774 & 0.7111 & -0.1663 \\
\hline
\end{tabular}

The decomposition of Buoyancy over the reform and Pre-reform periods

Table (4):

\begin{tabular}{lllllllll}
\hline Equation & Constant & Coefficient & $\begin{array}{l}\text { Lib. } \\
\text { Dummy }\end{array}$ & $\begin{array}{l}\text { Slope } \\
\text { Dummy }\end{array}$ & $\begin{array}{l}\text { 1991/92- } \\
\text { reform } \\
\text { Dummy }\end{array}$ & Trend & $\begin{array}{l}\text { Lagged } \\
\text { Base }\end{array}$ \\
\hline TTR & -.069 & 0.82 & 1.8 & -0.09 & 0.12 & 0.002 & 0.014 \\
& $(-.061)$ & $(3.21)$ & $(0.93)$ & $(-0.51)$ & $(0.63)$ & $(0.09)$ & $(.05)$ \\
\hline PIT & 0.21 & 1.26 & -3.89 & 0.61 & 0.08 & 0.23 & -1.22 \\
& $(0.20)$ & $(3.01)$ & $(-3.07)$ & $(3.83)$ & $(0.27)$ & $(4.31)$ & $(-3.37)$ \\
\hline CIT & -3.14 & 1.57 & 4.30 & -0.32 & 0.03 & 0.04 & -0.77 \\
& $(-1.50)$ & $(3.54)$ & $(1.13)$ & $(-0.84)$ & $(0.08)$ & $(0.52)$ & $(-1.82)$ \\
\hline IM.D & -1.89 & 0.83 & -0.46 & 0.001 & -0.16 & 0.04 & 0.01 \\
& $(-2.34)$ & $(4.98)$ & $(-0.48)$ & $(0.02)$ & $(-1.25)$ & $(1.25)$ & $(0.04)$ \\
\hline ED & -3.29 & 0.82 & 1.03 & -.01 & 0.49 & -0.13 & 0.27 \\
& $(-2.19)$ & $(2.75)$ & $(0.58)$ & $(-0.1)$ & $(1.98)$ & $(-2.19)$ & $(0.85)$ \\
\hline IND.T & -0.44 & 0.67 & 0.21 & 0.03 & 0.22 & 0.01 & 0.10 \\
& $(-0.52)$ & $(3.55)$ & $(0.16)$ & $(0.8)$ & $(2.16)$ & $(0.20)$ & $(0.47)$ \\
\hline DIR. T & -1.56 & 1.33 & 1.74 & -.06 & -0.24 & 0.12 & -.076 \\
& $(-0.61)$ & $(2.57)$ & $(0.38)$ & $(-0.31)$ & $(-0.87)$ & $(1.04)$ & $(-1.45)$ \\
\hline
\end{tabular}

Estimates of Tax Elasticity in Nigeria 1970-2010 
Table (5):

\begin{tabular}{|llllll|l|}
\hline & \multicolumn{2}{|c|}{ Buoyancy } & & Elasticity & $\begin{array}{l}\text { Difference } \\
\text { Coefficients }\end{array}$ \\
\hline Equation & Constant & Coefficient & Constant & Coefficient & \\
\hline $\begin{array}{l}\text { Total } \\
\text { Revenue }\end{array}$ & -1.33 & 0.92 & -0.07 & 0.82 & +0.10 \\
\hline $\begin{array}{l}\text { Personal } \\
\text { Income Tax }\end{array}$ & -4.16 & 0.95 & 0.21 & 1.26 & -0.31 \\
\hline $\begin{array}{l}\text { Business } \\
\text { Profit Tax }\end{array}$ & -3.88 & 0.96 & -3.14 & 1.57 & -0.61 \\
\hline Import Duties & -1.70 & & & & \\
\hline
\end{tabular}

Comparison of Nominal measures of Tax buoyancy and Elasticity Over 1970-2010

Table (6):

\begin{tabular}{|c|c|c|c|c|c|}
\hline \multirow[b]{2}{*}{ Equation } & \multicolumn{2}{|c|}{ Buoyancy } & \multicolumn{2}{|c|}{ Elasticity } & \multirow{2}{*}{$\begin{array}{l}\text { Difference in } \\
\text { Coefficients }\end{array}$} \\
\hline & Constant & Coefficient & Constant & Coefficient & \\
\hline $\begin{array}{ll}\text { Total } & \text { Tax } \\
\text { Revenue } & \end{array}$ & 2.95 & 0.25 & 4.33 & 0.52 & -0.27 \\
\hline $\begin{array}{l}\text { Personal } \\
\text { Income Tax }\end{array}$ & 3.03 & -0.18 & 4.16 & 0.02 & -0.2 \\
\hline $\begin{array}{l}\text { Business } \\
\text { Profit Tax }\end{array}$ & 2.59 & 0.02 & 5.25 & 0.58 & -0.56 \\
\hline Import Duties & 2.72 & 0.16 & 2.62 & 0.13 & +0.03 \\
\hline Excise Tax & -2.95 & 0.82 & -1.28 & 0.66 & +0.16 \\
\hline
\end{tabular}

Comparison of real measures of Tax buoyancy and Elasticity Over 1970-2010 